\title{
Study on the Effective Connection of Vocational Education in Architectural Interior Design
}

\author{
Qian Weng \\ College of Arts and Crafts, Liaoning Economic Vocational Technological Institute, Shenyang, \\ Liaoning, China 110122 \\ appleloveme@163.com
}

Keyword: Educational convergence; Secondary vocational education; Higher vocational education; Architectural interior design; Vocational education

\begin{abstract}
Through several decades of development of vocational education in China, it has formed a certain system and mode. Through combining the development of vocational education and the development of design industry, this paper summarized the connection mode of secondary vocational school and higher vocational school, made an analysis on the existing problem for connection of the secondary vocational and higher vocational education, to find effective ways and ideas to solve the problem.

In today's society, the strength of the country depends on the cultivation of talent to a certain extent, and vocational talent has gradually become the core of China's economic development [1]. To improve the professional ability, we must vigorously develop vocational education. In China's vocational education, secondary vocational education and higher vocational education pool a large number of professional personnel for the society, the level of vocational education to determine the level of socio-economic development, so the connection of these two levels of education has become the hot spots worthy of in-depth discussion.

The study of architectural interior design secondary and higher vocational education connection problem is to stroke healthy development from enrollment to education and then to employment, cultivate qualified professional design talent for the construction industry, in line with the industry's employment requirements, so that secondary vocational education graduates can successfully enter the vocational colleges to receive more systematic vocational education, for higher vocational colleges to cultivate a number of secondary vocational students with the more potential in vocational development, to promote the healthy development of vocational education system, establish the personnel training structure of vocational and technical education $[2,3]$.
\end{abstract}

\section{Effective Mode of Vocational Education in Architectural Interior Design}

At present, China's vocational education is divided into secondary vocational and higher vocational, the connection modes of secondary vocational and higher vocational in architectural interior design professional education system are in the following:

Counterpart Enrollment Mode. Mainly for secondary vocational school graduates to carry out independently selected test, academic system is 3 years, specialist diploma. After graduation, students can start work in society, or through the examination into the undergraduate institutions to continue their studies. This mode of education as a result of China's limited educational resources, is still the mainstream model still for China's secondary and higher vocational education.

Five-year System. This model is through joint school of secondary and vocational, most of them are the $3+2$ model, in the first three years, students accept the secondary vocational school management and training, then in the following two years, to accept vocational school management and training. There are some vocational colleges directly admitting junior high school graduates to enter higher vocational education for five years study, to accept the system of five years of training system.

Non-academic Cohesive Mode. This model is a higher vocational colleges through a certain assessment criteria, permitting the students who conform the standard of vocational students to 
continue to receive higher vocational education, so as to achieve the mode of education connection $[4,5]$.

\section{Analysis of the Problems and Causes of Effective Connection of Vocational Education in Architectural Interior Design}

Problems in Effective Connection of Vocational Education in Architectural Interior Design Specialty. Secondary vocational schools in practice teaching often have a more mature teaching mode, which is the result of long-term teaching accumulation, vocational students often have a strong on-site practical ability and professional design ability, while higher vocational colleges effected by higher education, the practical ability of the students are not necessarily higher than that of the secondary vocational schools. The practical teaching of the school is basically limited to the teaching of the virtual project in the studio and the study of the overseas project, resulting in "upside down" phenomenon of the practical design course of the architectural interior design major of secondary vocation and higher vocation, did not meet the level of vocational education requirements.

A few years ago, the architectural industry affected by the real estate industry to get greater development, employment needs gradually increased, which promotes the professional institutions to set up relevant major, but for the education model and training objectives, they lack research and demonstration. In recent years, the real estate industry showed a saturated state, the decline in demand for employment, resulting in individual institutions enrollment shrinking, on the other hand the fuzzy of training objectives and not unified mode of vocational training and skills setting are also gradually emerged, can't fully adapt to professional requirements.

Credits are recognized for students who are studying at school to achieve the course. Since the Ministry of Education promulgated the pilot work of the credit system in vocational school in 2001, many vocational institutions began to implement the credit system, but this credit system reform still stays on the surface, the state did not put forward specific requirements for the credit system, part of the vocational schools implementing the credit system are only mechanically setting the credits, and did not fundamentally implement the personnel training by the credit system.

Analysis on Reasons for the Effective Connection of Vocational Education in Architectural Interior Design. China's current higher education has vocational education and degree education, vocational education has secondary vocational education and higher vocational education, higher vocational education covers two kinds of education [6], which makes the higher vocational education sink into an embarrassing situation, most of the students who enter the higher vocation are whether with low scores of the college entrance examination scores and a small part of the secondary vocational students, resulting in different starting points for students and unified education model.

The reasons for the teacher

Teachers engaged in vocational education often graduated and directly enter the school to carry out teaching work, theoretical knowledge is complete, but the lack of industry practice experience, participation in the project or the proportion of independent projects are less, to grasp the practice of teaching teachers have less experience, resulting in disjunction between education and needs, affecting the development of students' professional skills.

The reasons for the connection of education

China's Ministry of Education did not set the corresponding classification and standards for the professional courses of vocational schools and vocational colleges, and the level of teaching in the same or similar courses was not clearly defined, resulting in vocational schools and vocational colleges setting the teaching outline, they make their own teaching content [6]. So in the course, it often appear that the same course teaching content are similar with same degree of difficulty, even in the vocational stage, the students have got the content in higher vocational school . 


\section{Countermeasure of Effective Connection of Vocational Education in Architectural Interior Design}

The effective connection of the architectural interior design needs to be put into the larger vocational education background in order to effectively implement them, which needs macro-adjustment of national policy and education management system, but also the adjustment of the industry needs, enrollment, credit system management, vocational qualification system and teachers team construction and other micro-various factors, through research, this article mainly from a micro perspective to sum up the implementation of high school curriculum convergence.

Depend on Industry Needs, to Determine the Training Model. The fundamental of vocational education is market-oriented, whether in training objectives, training programs, or curriculum settings, it should be consistent with the needs of the industry in order to ensure the sustainable development of vocational education.

Talent requirements for current enterprises on the ability are diverse, to form comprehensive ability. In short, there are five aspects: first, ideological and political elements; second, the quality of knowledge elements; third, the ability of quality elements; fourth, physical and mental quality elements; fifth, communication and cooperation elements of quality [7].

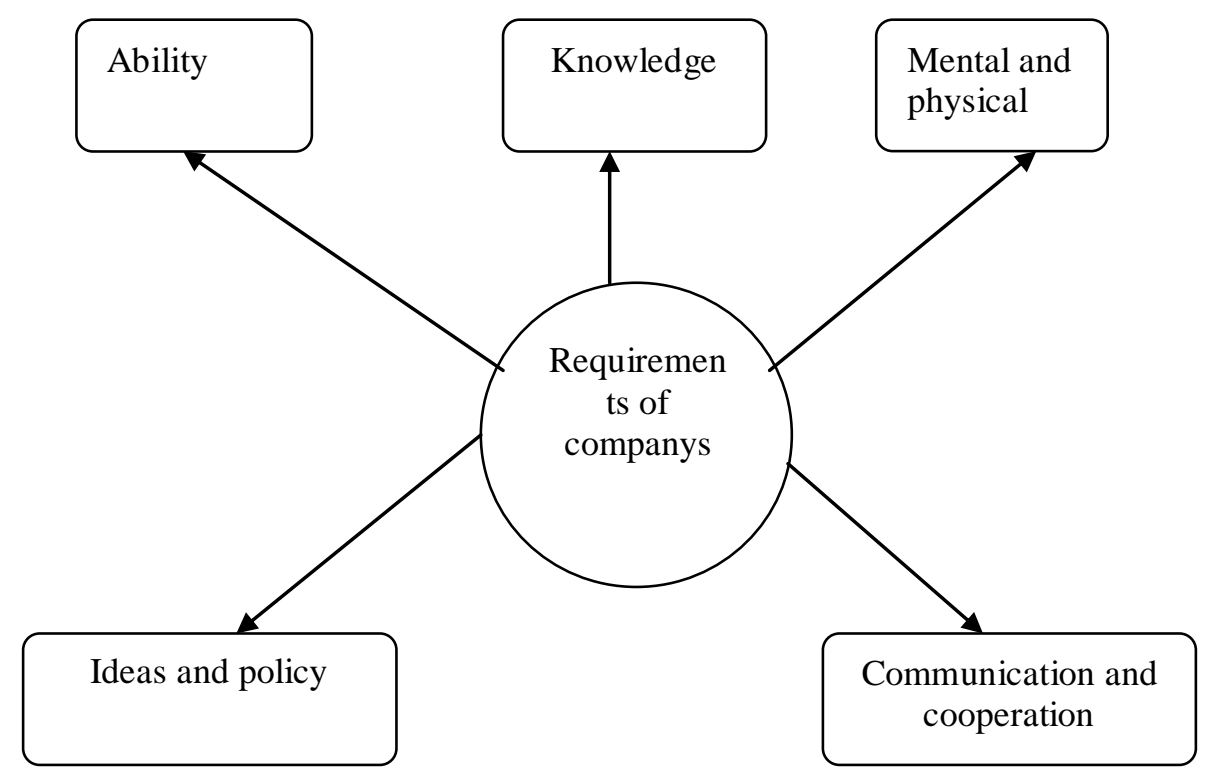

Figure 1. The requirements of professional and technical personnel for enterprises

The cultivation of professional talent is not only the knowledge of books and skills, but also need more and more soft ability, such as physical and mental communication and collaboration. Both in secondary vocational and higher vocational education, it needs to be consistent in the training model [8].

Vocational colleges should always conduct market research, grasp the dynamic changes in the market to determine the training objectives, personnel training programs and curriculum. This paper carrying out research is aimed at the enterprise's requirements of the interior design professionals, which mainly includes more than 20 enterprises in Liaoning Province.

Employers' experience in building interior design expertise (see Table 1) shows that good communication skills are the most needed capacity requirements, and graphic design capabilities and teamwork capabilities are two important indicators of the need for business. The model design and project independent design for the graduates is relatively loose. 
Table 1 Professional personnel capacity requirements for interior design professionals (\%)

\begin{tabular}{lllll}
\hline Professional capacity & $\begin{array}{l}\text { Very } \\
\text { important }\end{array}$ & Need & General & $\begin{array}{l}\text { No } \\
\text { need }\end{array}$ \\
\hline Communication ability & 90 & 10 & 0 & 0 \\
Photoshop 、 CAD 、3Dmax 、 Sketchup & 90 & 10 & 0 & 0 \\
computer drawing & & 10 & 0 & 0 \\
Color matching & 90 & 15 & 0 & 0 \\
Team cooperation ability & 85 & 15 & 0 & 0 \\
Design creativity & 85 & 10 & 5 & 0 \\
Office software operation & 85 & 5 & 5 & 5 \\
Plant scene setting & 85 & 5 & 15 & 0 \\
Effect image drawing & 80 & 5 & 20 & 0 \\
Graphic design ablity & 75 & 15 & 35 & 0 \\
Materials process & 50 & 20 & 30 & 5 \\
Model making ability & 45 & 50 & 20 & 0 \\
Project independent design & 30 & & & \\
\hline
\end{tabular}

Therefore, vocational education should be closely integrated with the needs of the industry, integrating the education process and industry needs. This involves the two aspects of problems in curriculum materials and school-enterprise cooperation.

First, the connection of teaching materials and industry

Vocational education materials need to reflect the characteristics of the industry. At present, the teaching materials of vocational colleges are mainly written by teachers in the school, and most of these teachers lack the practical experience of the industry, teaching materials can't fully reflect the practical value. This requires the introduction of industry talents into the preparation of teaching materials, integrating the theoretical knowledge of the school teachers and practical experience of industry talent together to form a more complete knowledge system in line with the characteristics of vocational education.

Second, take school-enterprise cooperation training model in the education process

We cultivate students with vocational skills, which needs students to be able to adapt to the working state of the enterprise, in order to allow students to adapt to the work of enterprises after graduated from school as soon as possible, vocational schools have carried out school-enterprise cooperation training model. Shanghai Institute of Arts and Crafts Crystal College and WPP College is the new model of the school-enterprise cooperation to achieve that the students are cultivated by the enterprise in three years, enterprises directly involved in the education process, implementing enterprise management, so that students can feel the company's work process in the learning process.

To Implement Enrollment. Vocational colleges, especially higher vocational colleges should form a unified vocational education admission standards, and in the entrance examination, it should not restricted by the traditional enrolment condition, changing from the original focus on the examination to focus on practical ability and professional ability assessment. Through the enrollment entrance examination standards, to redefine the two levels of vocational education professional standards and curriculum, and curriculum standards to reflect the level of requirements, in order to promote the effective connection of vocational education.

To Implement Credit Management. The connection of the curriculum system of secondary vocational and higher vocational schools should be based on the credit system and the implementation of dynamic and flexible connection. By credits standards issued by the education department, to require students to complete the school courses during the school including a few 
basic courses, specialized courses, which one is required courses, which is elective courses. Secondary vocational and higher vocational qualifications should have corresponding number of credits [9]. This requires to form a unified credit standard system under the guidance of the education department in order to make credit and credit system recognized by vocational institutions.

To Develop Vocational Skills to Obtain the Relevant Professional Certificate. The acquisition of vocational qualification certificates at all levels is also a test of the direction of vocational education, while vocational qualification certificates in the industry also occupy a higher status. Whether in secondary vocational or higher vocational, according to the level of training to encourage and train students to obtain industry professional qualification certificate. Forming a mature professional qualification assessment standards, beneficial to promote the development of vocational education. The development of different levels of vocational qualification examination also help secondary vocational and higher vocational training at different levels for vocational talents, to avoid duplication and waste of educational resources. In this case, to form a vocational education vocational qualification system will be contributing to the connection of high education system.

To Build a Strong Teacher Team. Professional ability and practical ability of vocational college teachers is the premise to cultivate excellent professional talents, so vocational institutions must have a teacher team with high theoretical knowledge and high practical ability. This requires vocational teachers to continue to strengthen their own theoretical knowledge structure, but also to continuously improve their professional practice ability, and constantly improve the teaching model and teaching content, to strengthen the understanding of the development of the industry. Therefore, vocational schools need to improve the training system for teachers, and encourage teachers to go out to participate in industry practice training, exercise, and obtain the relevant vocational qualification certificate, training "double teacher mode" teachers.

The education regulations for secondary vocational and higher vocational institutes need to be improved and the education process needs to be required strictly, especially in practice teaching, to implement a wide range of multi-channel supervision and management. Vocational colleges should focus on the assessment of teachers' practical teaching ability, and taking this ability into the evaluation system. Increase assessment and incentives of the practice teaching to help teachers to introduce the project, but also strengthen the exchange between school and enterprises, so that vocational education always walk in the forefront of the industry [10].

\section{Conclusion}

In short, in order to truly achieve the effective connection of secondary vocational and higher vocational education, we should establish a unified vocational education system, and vocational education system should be exclusively controlled by professional education department, to distinguish subject education, clearly know the training objectives of vocational education, in order to gradually build a more reasonable education system and reduce unnecessary education consumption in the connection, to promote the formation of progressive vocational education system.

\section{References}

[1] J. Liu: Strategic construction of legal undergraduate curriculum system (MS., Capital Normal University, China 2007), p.18.

[2] B. Yang: Research on Curriculum Optimization of Accounting Major in Zhejiang Province (MS., Journal of Zhejiang Normal University, China 2007), p.21.

[3] Q. Tan: Study on curriculum connection of higher vocational education based on modern vocational education system (Ph.D., Southwest University, China 2016), p.36.

[4] S.Q. Qi: Research on the connection of higher vocational education (Ph.D., Journal of East China Normal University, China 2016), p.27. 
[5] Y. An: Research on the construction of connecting course system in higher vocational education (MS., Journal of Shanghai Normal University, China 2012), p.11.

[6] Ministry of Education: 2010 National Education Development Statistics Bulletin (China Education News, China, July, 6, 2011). p.2.

[7] S.L. Liu, C.F. Ji and X.X. Ye: China Vocational and Technical Education, Vol. 9 (2014) No.9, p. 27-31.

[8] L.L. Liao: Education Modernization, Vol. 14 (2017) No.14, p.111-112,115.

[9] S. L and Z.G. L: Science and Technology Outlook, Vol. 24 (2017) No.24, p. 226.

[10]D.Y. Jiang: Vocational Education New Theory (Educational Science Press, Beijing 2007). 